\title{
Moderating Effect of Firm Characteristics on the Relationship between Electric Power Outage Dynamics and Financial Performance of Manufacturing Firms in Kenya
}

\author{
Winfred Wanjiku Njiraini, PhD Candidate \\ Prof. Mirie Mwangi \\ Prof. Erasmus Kaijage \\ School of Business, Department of Finance and Accounting, \\ University of Nairobi, Kenya \\ Prof. Pokhariyal Ganesh \\ School of Mathematics, Department of Applied Mathematics, \\ University of Nairobi, Kenya
}

Doi:10.19044/esj.2021.v17n1p256

Submitted: 21 November 2020

Accepted: 08 January 2021

Published: 31 January 2021
Copyright 2021 Author(s)

Under Creative Commons BY-NC-ND

4.0 OPEN ACCESS

Cite As:

Njiraini W.W., Mwangi M., Kaijage E., \& Ganesh P. (2021). Moderating Effect of Firm Characteristics on the Relationship between Electric Power Outage Dynamics and Financial Performance of Manufacturing Firms in Kenya. European Scientific Journal, ESJ, 17(1), 256. https://doi.org/10.19044/esj.2021.v17n1p256

Abstract

Past literatures on the correlational link between electric power outage dynamics and performance of manufacturing firms, in most economies, have portrayed a controversial conceptual debate amongst scholars with little focus on the moderating role played by firm characteristics. This paper focuses on determining the effect of firm characteristics (capital structure) on the relationship between electric power outage dynamics and financial performance of manufacturing firms in Kenya. Positivism philosophical point of view and descriptive survey research design was utilized. A population of 447 manufacturing firms in Kenya, which were also members of Kenya Manufacturers Association, was selected out of which a sample size of 138 firms was drawn using stratified random sampling methodology. Structured questionnaires were utilized to collect data which involved drop and pick approach. The research results indicate that the relationship between electric power outage dynamics and performance of manufacturing firms in Kenya is not significantly moderated by firm characteristics. This study outcome 
augments existing knowledge on electric power outage dynamics in relation to firm characteristics and financial performance. This is because it is evident that top management should not focus on capital structure as a conditional factor when making decisions aimed at enhancing firm financial performance under power outage conditions. The study has also made an input to the academic literature ascending from empirical reinforcement of tradeoff theory and pecking order theory in making determination on firms' capital investments. Policy makers and power utilities benefit in understanding the negative effect of power outages on the performance of firms are therefore guided in overseeing the planning and implementation of proper electricity infrastructure. Kenya Association of Manufacturers (KAM) will find these research findings useful in guiding their member firms on strategies to adopt to ensure continuous productivity and safeguard damages to the firm as a result of electric power outages.

Keywords: Electric Power Outage Dynamics, Firm Characteristics, Financial Performance

\section{Introduction}

Electricity is a fundamental input factor for many production processes and is also the dominant source of energy for firms (Karen, Erin \& Qiong, 2015). The major role of energy in most firm productivity endeavors renders any deficiencies negative to production efficiencies and further results into a reduction in output (Abotsi, 2015). Inefficient supply of electricity is portrayed by electricity unreliability characterized by power outages and/or power quality oscillations (Eto et al., 2001). Although adverse influence of electricity power outage is evident in most economies, the extent to which this damage occurs depend on other moderating variables such as firm characteristics (Dean, Bülent \& Christopher, 2000).

Firm characteristics are the managerial and demographic features that differentiate one organization from others such as firm size, leverage, liquidity, firm growth rate, asset growth, and turnover even when operating in the same industry. It also describes the unique internal factors surrounding the firm. Further perspectives that are useful in distinguishing the firm and are categorized as firm characteristics include firm ownership layout, board of director features, firm age, ease at which a firm accesses debt from the capital bourse, and available opportunities to grow (Subrahmanyam \& Titman, 2001).

Kouki and Guizani (2009) defined capital structure as the combination of the debt and equity of a company. This structure is also referred to as the debt equity ratio or gearing ratio which is expressed as the quotient of longterm debt to owners' claim. It is a ratio that depicts the level of utilization of both internal and external financial resources of an organization in facilitating 
capital ventures within a certain time frame, usually per annum (Gill, Biger \& Tibrewala, 2010). One of the most efficient mechanisms to manage the cost of capital is through capital structure. An optimum capital structure is attained at the point of minimum cost of the capital (Ellili \& Farouk, 2011). Corporate finance considers the cost of capital to be one of the most important issues. As a result, firm managers strive to maintain a capital structure that minimizes financial and business risks on the firm, while maximizing shareholders' wealth through positive effect on firm performance (Green, Murinde \& Suppakitjarak, 2012).

An electric power outage is a short or long-term loss (supply interruption) of electric power (Eto et al., 2001). Power outage is a major challenge for firms and has a negative effect on the productivity and performance of firms (Cissokho \& Seck, 2013; Allcott, Allan \& Stephen, 2014). These effects manifest in various ways within the firm which includes: effect on firm efficiency, additional costs to the firm's production processes through investment in alternative sources of energy or costs incurred in replacement or repairs of affected equipment due to power outages, and impact on the quality of goods or services as a result of power outage (Cissokho \& Seck, 2013). Therefore, these dynamics have an adverse impact on firm performance in a variety of ways (Steinbuks \& Foster, 2010). Electric power outages are characterized by dynamics which may include aspects such as time of occurrence of the outage, length/duration of outage, frequency of outage, source of outage, perceived reliability level of power supply and notification of outage, or lack of it among others (Nooij, Koopmans \& Bijvoet, 2007).

Power outage frequency or number of occurrences refers to the number of power blackouts over a specific time period, either per day, week or on monthly basis. Power outages may also be defined based on fluctuations of electricity supply in a certain locality (Schoeman \& Saunders, 2018; Moyo, 2012). Power outage duration measures the amount of time the curtailed supply of electricity is experienced by individual or commercial customers (Fisher-Vanden, Mansur \& Wang, 2015). The duration of the power outage is known to determine the costs of the interruption to firms (Nooij, Koopmans \& Bijvoet, 2007). Power outage frequencies and the duration are characteristics that are known to trigger strains for some industries, mainly those that rely on electricity as a major input resource (Frederick \& Selase, 2014).

Power outage notification is an advance communication to end users of electric power within a reasonable duration before the power outage. A notification before an interruption lowers the consequences of that interruption (Nooij, Koopmans \& Bijvoet, 2007). On the other hand, unmitigated loss due to lack of notification may cause various damages that may affect product quality and cause significant increase in costs of operations (Lai, Yik \& Jones, 2008). The time of electric power outage is also a component of electric power 
outage dynamics. This perspective refers to the timing of blackout occurrence whether planned or unplanned (Frederick \& Selase, 2014). The time power blackouts occurrence has diverse implications such as the number of users affected and the costs thereof.

Firm performance is the firm's effectiveness and efficiency in which it conducts its affairs (Chakravathy, 1986). Organizational performance is defined as a set of fiscal and non-fiscal parameters based on the level of attainment of objectives and outcomes (Lebans \& Euske, 2006). This study considered the financial based Return on Assets to measure performance of firms in the manufacturing sector in Kenya, which are also members of Kenya Association of Manufacturers (KAM). The choice of this class of firms is backed by the following reasons: First, electricity is a major input of the firm production processes and, therefore, a disruption in electricity supply has a significant impact on the operations of the firms. Second, manufacturing firms in Kenya comprise of firms in varying categories of industries that provide heterogeneous analysis of the impact of electric power outage dynamics on the performance of firms.

The capital structure to firm performance linkage varies from one firm to another across various industrial set ups in any country. In some cases, the association could be positive and others negative (Dhillon, 1986). For firms involved in production and with a heavy reliance on electricity as a source of input to production, organizational characteristics such as capital structure influence their coping mechanisms to avert the negative effects of power outages.

The relationship amongst electric power outage dynamics, firm characteristics, and performance is underpinned by trade-off theory proposed by Myers (1984) and the pecking order theory by Myers and Majluf (1984). The trade-off theory hypothesizes that a profit maximizing firm will endeavor to ensure that it maintains a balance between marginal benefits and marginal costs when a firm is maintaining some cash balances and investing in capital goods. Thus, this is with the aim of avoiding cases of impairment between liquidity and profitability. When a firm is planning to invest in a profitable opportunity, there are benefits and costs to that effect. The theory underscores an equilibrium between a reduction in bankruptcy, financial distress costs, and agent costs with tax saving arising from debt. The optimal leverage level is obtained by balancing the costs of debt issue and the benefits from interest payments. On the other hand, the pecking order theory advocates the use of cheapest sources of finance before opting for the costly alternative. In view of the above theories, capital structure optimality has a potential effect to regulate financial and/or business risks to a firm that may arise due to power outages and their resultant impact on firm performance in pursuit of shareholder wealth maximization. 
Therefore, this paper focuses on determining the effect of firm characteristics on the relationship between electric power outage dynamics and performance of manufacturing firms in Kenya. The paper seeks to provide greater insights on a critical input to manufacturing firm's production process - the electric power outage dynamics and their resultant impact on firm performance. Capital structure moderation of these variables is also analyzed. Such analysis have hardly been undertaken for Kenyan firms other than in generalized studies based on panel data sets. Thus, the outcomes of these studies provide generalized data that may not be fully relied on for Kenyan manufacturing firms, which is a gap this paper seeks to fill. In addition, the paper seeks to make contribution to existing body of theoretical knowledge, managerial policy, and practices. The paper covers various sections as follows; introduction, literature review, research methodology, results and discussions, and conclusion.

\section{Literature Review}

A review of the literature reveals that electric power outages have varying degrees of impact of firms in various jurisdictions. The critical role of electricity as a firm input is common in most studies, with varying actions undertaken to mitigate effects of power failure. The coping mechanisms in such dire situations are influenced by firm characteristics. The characteristics of a firm are dominated by the demographic and decision-making qualities that make a distinction between one firm and another. Firm characteristics describe elements of its internal environment. Hence, organizations are demarcated by variables such as firm size, capital structure, liquidity, age of the firm, access to capital markets, and growth opportunities (Zou \& Stan, 1998).

Abdisa (2018) in a study of Ethiopian firms examined the characteristics of power outages and their resultant response to mitigate the outages towards safeguarding firm performance. The study found that power outages increased unit costs of production by $15 \%$ through factor adjustments and this have affected firm productivity negatively. Firms substituted grid supplied electricity through self-generation during periods of power outages, the factor share of electricity and capital decreased, and overall, the output level suggested that outage is particularly costly for large firms.

Adewuyi and Emmanuel (2018) evaluated the moderating role of corruption in mitigating the effect of electricity outages on firm performance across the six geo-political zones in Nigeria. In addition, the study analyzed the effect of self-generation on firm performance across the six geo-political zones and comparison was made as to whether it is more profitable for firms to self-generate electricity during outage periods or bribe electricity officials to mitigate the effect of electricity outages on their performance. The study 
employed a cross sectional Ordinary Least Squares (OLS) and Two-Stage Least Squares (2SLS) techniques. The study found that bribery mitigated the effect of electricity outages on some geo-political zones and not others. In addition, self-generation was found to be a form of indirect tax which had a negative effect on firm performance.

In another study by Bawuah and Anaman (2018), the aim was to establish whether power outages in Ghana had an effect on performance of firms listed at the Ghana Stock Exchange. Explanatory research design was adopted and quantitative methods employed. Thus, this made it possible to carry out trend analysis of six years of firm performance 'before' and 'during' power outage periods. The sample size selected entailed 25 firms from a population of 35 firms using purposive sampling technique. Key performance indicators measured include profitability, revenue, and growth rate. The research conclusions were contrary to the past studies as power outages did not have an adverse outcome on revenues of listed firms. In this study, the firms attained greater maximum revenues for periods when power outage was experienced. An average growth rate of 122.26 percent was achieved for periods of power outages against 79.0 percent mean rate of growth for periods with consistent power supply. The study therefore concluded that power outages had no effect on the growth rate of listed firms in Ghana. However, power outages had an influence on the profitability of listed firms' and more so, were responsible for a significant increase in operation expenses.

In the study of Oseni and Pollitt (2013), the researchers investigated the effect of firm characteristics in the creation of incentives for backup generation leading to reduced unmitigated outage costs. The study was conducted in 12 African countries and involved 6854 firms. The study evaluated the effect of firm characteristics as the independent variable towards motivating firms to self-generate power and investigate whether these motivations led to lesser unmitigated outage costs that affected a firm performance. The study used cross-sectional data and applied incomplete backup, marginal cost, and individual assessment methodology. It was concluded in the study that firms which concentrated on export transactions, big firms, and those that required the internet for operations suffered greater outage costs that were not mitigated notwithstanding their greater inclination to venturing in the self-generation of electricity. Unmitigated costs of power outage accounted for the bigger share of total costs of outage notwithstanding the high levels of backup power generation investments. Also, there is an indication of a low level of backup investment as a result of small capacity of back up accessed by firms.

Alam (2014) conducted a study in India to evaluate the effect of power outage on firm size, productivity levels, and profitability. The analysis adopted a model to generate comparative static predictions about input choices, output, 
and changes in profits while increasing the occurrence of power outages. The conclusion of the study indicated that the effect of power outage differs across industries. In some power-intensive industries, increased frequency of outages was found to lower production and profits, while some industries were less affected due to availability of greater adaptation mechanisms. For instance, a rise in the occurrence of power outages lowered the yield and returns of only some electricity-intensive industries. In addition, the study found that shortrun changes in power outages do not induce firms to install back up power generators. This study was bivariate for the focus was on the link between power outage and profitability, firm size, and productivity.

In a similar study by Moyo (2012), the aim was to evaluate the impact of power supply interruptions on productivity of firms in the manufacturing sector of Nigeria. Tobit and OLS models were utilized. Productivity variables that were used as outcome factors were estimated using plant and machinery replacement costs. Output was measured using sales total value, while material inputs were measured using total expenses of direct materials and transitional items utilized in production. The age of the firm was computed by determining the change in duration between the year the organization was incorporated and the year the study was undertaken. Firm size was computed based on the number of workers engaged. All firms with less than twenty workers were categorized as small and the large one had more than 20 employees. The aim of using this methodology was to assess whether power outages affected firms arbitrarily or whether the impact depended on the firm's size. Power outage was estimated by the number of days firms experienced power outage per month, the number of hours a firm went without power per day, and the percentage of yield lost due to power outages in any given year. The research finding revealed that power outage variables had adverse and significant consequence on productivity, more so for small firms. It was further depicted that inadequate electric supply had an inverse impact on the growth rate of small and medium businesses, and operational costs increased significantly during periods that power outages were experienced. The cost of backup power source also pushed up the cost of business operations significantly and therefore negatively affected performance.

Oladele, Omotunde and Adeniyi (2017) also conducted a study which classified capital structure as an independent variable. The study assessed the influence of capital structure on performance of listed organizations at the Nigeria Stock Exchange from 2004-2013. The study is set to establish the general impact of capital structure on corporate performance of the quoted organizations by ascertaining the linkage between determination of capital structure of Nigerian firms and their ROE, ROA, EPS and turnover growth rate. Here, the factors were used as proxies to measure corporate performance. 
Multiple regression was used to carry out the data analysis. The study outcome depicted that capital structure did not have substantial impact on ROE but had significant impact on ROA, Earning per Share (EPS), and sales growth of listed manufacturing firms in Nigeria. The study advocated for the listed firms critical need to ensure optimization of capital structure so as to increase the returns on equity, assets, and earnings per share.

Saeedi and Mahmoodi (2011) carried out a study to determine the correlation between the capital structure and the performance of firms listed at the Tehran exchange bourse. The outcome of the study was that there was a direct association between market related measures of performance and capital structure. ROE and capital structure did not have significant association, while ROA had a positive link to capital structure. Hence, the study concluded that financial leverage has a significant impact on the various measures of performance in distinct ways.

Kisengo and Kombo (2014) carried out a study in Nakuru, Kenya to assess the impact of firm characteristics on performance of microfinance sector. Both primary and secondary data was gathered through the use of questionnaires. Using census approach, analysis was conducted for the 48 registered microfinance institutions. Firm characteristics and organizational performance were analyzed using descriptive statistics. Relationship between firm characteristics and performance was interrogated using correlation analysis. Furthermore, the impact of firm characteristics on the performance of microfinance institutions was done using regression analysis approach. It was established that firm characteristics had statistically significant direct effect on performance of MFIs. Features that were capital related had the least effect on performance of microfinances, whereas those that were structure related had the greatest impact.

Over the years, the debate on the association between electric power outage dynamics and financial performance of manufacturing firms has been characterized by conflicting results amongst scholars. Various studies on the extent to which electric power outages affect performance of firms have been carried out in well-developed economies including Germany, China, India, and Pakistan. Whereas little attention has been given to developing countries in Africa, with the exception of Nigeria, to which a considerable number of studies pertaining the same subject matter of power outage dynamics have been undertaken. Past studies revealed mixed outcome on the influence of firm characteristics on financial performance of firms. Most past studies on determinants of firm performance were bivariate and categorizes firm characteristics as pure predictors without testing their probable moderating role in the association between power outage dynamics and financial performance. Furthermore, the research findings on this association by 
scholars portrayed dissimilar results although some of the factors incorporated in the study were the same.

The current study is focused on the moderating role that firm characteristics (capital structure) has on the relationship between electric power outage (outage frequency) and financial performance. The study hypothesized that the relationship between electric power outage dynamics and financial performance of manufacturing firms in Kenya is not moderated by firm characteristics.

\section{Research Methodology}

This current study made use of positivism philosophical paradigm and descriptive survey research design respectively. A population of 447 firms whose main area of focus is manufacturing in Kenya and were also members of Kenya Manufacturers Association was considered out of which a sample size of 138 of such firms was selected. Structured questionnaire were utilized to collect data which involved drop and pick methodology for five years from 2014 to 2018. Questionnaire return rate was used to present the percentage of the successfully returned questionnaires.

The conforming null supposition stated that the relationship between electric power outage dynamics and performance of manufacturing firms in Kenya is not significantly moderated by firm characteristics. A two-step stepwise multiple regression process was carried out to test the null hypothesis. To establish the moderating effect of industry (Baron \& Kenny, 1986; Aiken \& West, 1991), this approach was used. The guideline entails, first, fitting a regression model (model 1) to test the main effects of the predictor variable and the proposed moderator. Step two of Baron and Kenny (1986) involves entering the interaction term in the previous model (model 1) so as to generate a second model (model 2). The interaction term is developed by determining the product of the predictor and the moderator.

Data analysis was undertaken using SPSS computer software version 21. Coefficient of variation and standard deviation were applied to analyze the variability of association amongst the variables. The strength of fit was assessed using the coefficient of multiple determination. Measures of dispersion were applied to investigate the fundamental qualities of the data collected for the analysis. This study incorporated Electric power outage dynamics-frequency as the predictor variable. Nonetheless, financial performance was the dependent variable and return on assets was used as the proxy. 


\section{Results and Discussion}

\section{Questionnaire Return Rate}

To determine the questionnaire return rate, the number of questionnaires received from the respondents as compared to those issued was analyzed. Thus, the results are indicated in Table 1 below.

Table 1. Questionnaire Return Rate

\begin{tabular}{llll}
\hline Particulars & Returned & Not Returned & $\begin{array}{l}\text { Distributed } \\
\text { Questionnaires }\end{array}$ \\
\hline Frequencies & 73 & 65 & 138 \\
Percentages & $53 \%$ & $47 \%$ & $100 \%$ \\
\hline
\end{tabular}

Out of 138 questionnaires which were distributed, 73 were returned inclusive of 6 , which were totally spoiled (returned with no useful information). Therefore, 67 were properly filled and returned. This translates to a $51 \%((73-6) / 132)$ questionnaire return rate. This response rate is acceptable as per Richardson (2005) who regards a questionnaire return rate of at least $50 \%$ as being acceptable in social research survey.

\section{Electric Power Outage Dynamics}

Electric Power Outage Dynamics (EPOD) is represented by power outage frequency indicator as follows;

\section{Power Outage Frequency}

The rate at which power supply involuntarily goes on and off is critical to manufacturing firms. This is because the more frequent the power outage, the more unreliable it is. Therefore, each firm's officials were requested to give their opinion pertaining the extent to which power outage occurred (frequency) in a month and responses were obtained as shown in Table 2.

Table 2. Power Outage Frequency

\begin{tabular}{lll}
\hline & Frequency & Percent $\mathbf{( \% )}$ \\
\hline $\mathrm{X}<5$ Times & 25 & 37 \\
5-10 Times & 34 & 51 \\
11-15 Times & 4 & 6 \\
16-20 Times & 1 & 1 \\
Over 20 Times & 3 & 5 \\
\hline Total & 67 & 100 \\
\hline
\end{tabular}

Power outage frequency was not high for the majority of the firms $(88 \%)$ that reported up to 10 cases of blackout occurrences in a month. Whereas, $12 \%$ of the manufacturing firms experienced over 10 outages in a month. 


\section{Financial Perspective}

The study further interrogated the financial performance trend for the manufacturing firms in Kenya for five years from 2014 to 2018. Descriptive data analysis from the data provided by the respondents is shown in Table 3 below.

Table 3. Financial performance

\begin{tabular}{lllllllll}
\hline Var & n & Mean & SD & CV & Min & Max & Sk & Kurt \\
\hline EBIT & 67 & 576.24 & 1862.276 & 3.232 & -363 & 9837.4 & 4.003 & 18.668 \\
ROA 67 & 13.986 & 14.358 & 1.027 & 21.85 & 56.67 & 0.142 & 4.554 \\
\hline
\end{tabular}

In the case of financial performance, data from the firms depicted that financial performance was presented by Profit Before Tax and Return on Assets. The latter is a quotient of Earnings Before Taxation and Total Assets which is made up of both fixed and current assets. The average Profit Before Tax for manufacturing firms is approximately Kshs. 576 million with most profitable firm making a profit of about Kshs. 9.8 billion (see Table 3). The least profitable firm made a loss of about Kshs. 363 million. The average return on assets among manufacturing firms was about $13.98 \%$. The firm which made least profits had a negative return of about $22 \%$, while the highest firm had a positive return of over $57 \%$. Profit Before Tax had the highest variation while Return on Assets had the least variation. Only Return on Assets had a skewness value that is close to zero and a kurtosis value that is close to three. Therefore, it is likely to be normally distributed unlike Profit Before Tax and Total Assets whose skewness and kurtosis value are far from zero and three respectively.

To establish the moderating effect of firm characteristics, capital structure (Baron \& Kenny, 1986; Aiken \& West, 1991) approach was used. The guideline entailed, first, fitting a regression model (model 1) to test the effects of the predictor and the proposed moderator factors which present the main effect. The effect for both the predictor and the moderator should be significant and also the model in general $\left(\mathrm{R}^{2}\right)$. Step two involved entering the interaction term in the previous model (model 1) to generate a second model (model 2). Hence, a hierarchical multiple regression was performed.

Consequently, the moderation results of capital structure as a component of firm characteristics is shown in Table 4 below. 
Table 4. Results of Hypothesis Testing of EPOD and Financial Performance as Moderated by Capital Structure

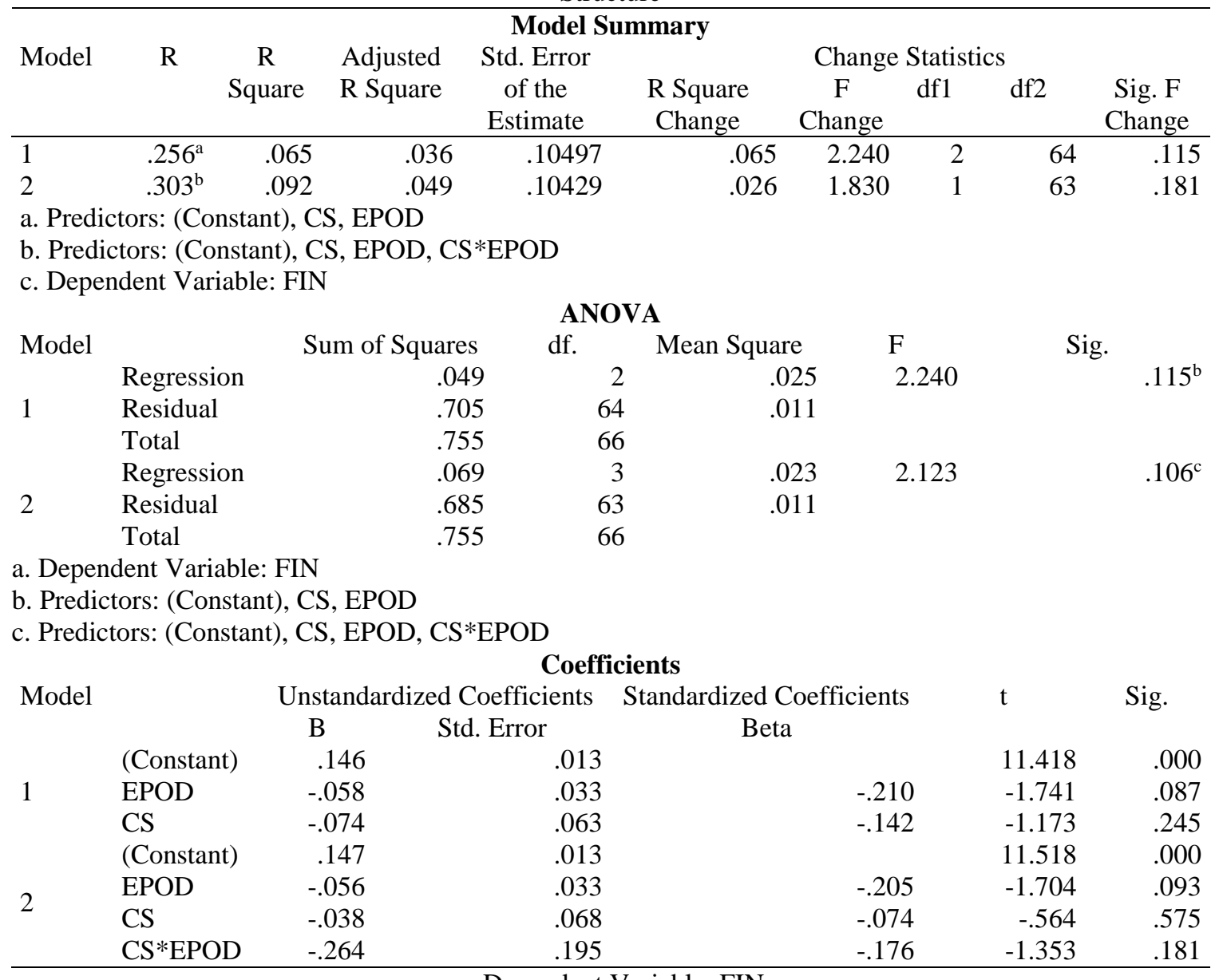

a. Dependent Variable: FIN

From Table 4, both model 1 and model 2 computed did not show statistically significant moderating effect of capital structure on EPOD and financial performance. Thus, this is because the effect for both the predictor and the moderator was not statistically significant and also the model in general $\left(\mathrm{R}^{2}\right)$. Therefore, it was depicted that no moderation effect was inferred for both the main effect and the new interaction term as they did not significantly influence financial performance.

\section{Conclusion}

The negative effect of electric power outage on performance of firms is documented in the current study as well as in various studies such as Abdisa (2018), Adewuyi and Emmanuel (2018), Alam (2014), and Oseni and Pollitt (2013) among others. However, in the current study, the firm characteristics, 
i.e., capital structure, did not depict moderation effect on the relationship between electric power outage dynamics and financial performance of manufacturing firms in Kenya. The research findings portrayed that capital structure is not a conditional factor when making decisions aimed at enhancing firms' financial performance as a result of negative effects of electric power outages. Top management of manufacturing firms therefore should not have a consideration of leverage in making decisions on ameliorating negative effects of power outage on financial firm performance.

In connection to the current research findings, past studies portrayed both similar and dissimilar outcomes pertaining to the influence of capital structure on firm performance. Similar studies that did not establish significant influence of capital structure on financial performance include Oladele, Omotunde and Adeniyi (2017) that established that no statistically significant association existed between capital structure and return on equity. However, in the case of return of assets (ROA), earnings per share (EPS) and sales growth of listed manufacturing firms in Nigeria, it was portrayed that a statistically significant association prevailed. Furthermore, in the study of Saeedi and Mahmoodi (2011) that aimed interrogating the link between capital structure and performance of firm listed at Tehran Stock Exchange, the study findings portrayed that capital structure and performance has a direct correlation. In Kisengo (2012), ROA was positively related to capital structure, while ROE had no statistically significant association with capital structure.

This study shows that policy makers benefit in understanding the effect of poor quality of power supply on the performance of firms. As a result, they are guided in overseeing the planning and implementation of proper electricity infrastructure that will eliminate inefficiencies in power supply as experienced during power outages. In addition, the study also provides power utilities information that will aid their investment in adequate infrastructure and enhanced maintenance towards efficient power supply to firms at all times. This study also provided information to the power and petroleum sector regulatory body, i.e., the Energy and Petroleum Regulatory Authority (EPRA), which would enhance the protection of power consumers and manufacturing firms, for whom power outages have negative effects on performance. The regulator could put in place punitive mechanisms to power utilities when power outages are experienced due to their acts or omissions. This should work to minimize power outages and resultant effects on consumers. Top management of manufacturing firms are also advised that the level of leverage has no impact when determining effective ways of mitigating negative effects of power outages on firm performance. Subsequently, suitable mitigation may be found in seeking backup generation facilities during periods of power outage. 
This study had a limited focus on manufacturing firms registered under KAM; hence the contextual gap emanating from global, regional, and local perspectives of manufacturing firms with no affiliation in membership with KAM has not been fully realized. Future research activities could focus on wider scale of firms. In addition, future studies could evaluate additional moderators based on the relationship between electric power outage on firm performance as firm characteristics (capital structure) did not have a moderating effect on this relationship.

\section{References:}

1. Abdisa, L. T. (2018). 'Power Outages, Its Economic Cost and Firm Performance: Evidence from Ethiopia', Utilities Policy, 53: 111-120.

2. Abotsi, A.K. (2015). Foreign ownership of firms and corruption in Africa. International Journal of Economics and Financial Issues, 5(3), 647-655.

3. Adewuyi, A. O. \& Emmanuel, Z. (2018): Electricity Outages and Firm Performance across the Six Geo-Political Zones in Nigeria: The Role of Corruption - MPRA Working Paper Series

4. Aiken, L. S. \& West, S. G. (1991). Multiple regression: Testing and interpreting interactions. Thousand Oaks, CA: Sage.

5. Alam, M. (2014). Coping with blackouts: Power outages and firm choices. Ph.D. Thesis, Yale University, New Haven, CT, USA.

6. Allcott, H., Allan, C.W. \& Stephen, D. (2014). How do electricity shortages affect productivity? Evidence from India. American Economic Review, 106(3), 587-624.

7. Baron, R. M. \& Kenny, D. A. (1986). The moderator-mediator variable distinction in Social Psychological Research: Conceptual, strategic, and statistical considerations. Journal of Personality and Social Psychology, 51(6), 1173-1182.

8. Bawuah, B. \& Anaman, D.K. (2018). Power outages in Ghana: Did they have an effect on the financial performance of listed firms? International Journal of Management Excellence, 3(10), 1434-1439.

9. Chakravathy, B. S. (1986). Measuring strategic performance. Strategic Management Journal, 7(5), 437-458.

10. Cissokho, L. \& Seck, A. (2013). Electric power outages and the productivity of small and medium enterprises in Senegal. ICBE-RF Research Report N0. 77/13.

11. Dean, D. L., Christopher. P. \& Bülent, M. (2000). Revisiting Firm Characteristics, Strategy, and Export Performance Relationship: A Survey of the Literature and an Investigation of New Zealand Small Manufacturing Firms. Industrial Marketing Management, 29, 461477. 
12. Dhillon, U. P. (1986). Corporate ownership, dividend policy, and capital structure under asymmetric information. (Ph.D. Thesis) Louisiana State University and Agricultural \& Mechanical College.

13. Ellili, N. O. D. \& Farouk, S. (2011). Examining the capital structure determinants: Empirical analysis of companies traded on Abu Dhabi Stock Exchange', International Research Journal of Finance and Economics, 67(12), 234-241.

14. Eto, J. J., Koomey, B., Lehman, N., Martin, E., Mills, C., Webber \& Worrell, E. (2001). Scoping study on trends in the economic value of electricity reliability to the U.S. economy. Lawrence Berkeley National Laboratory. LBNL-47911. June. Berkeley CA.

15. Fisher-Vanden, K., Mansur, E. \& Wang, Q. (2015). Electricity Shortages and Firm Productivity: Evidence from China's Industrial Firms. Journal of Development Economics, 11(4), 172-188.

16. Frederick, D. \& Selase, A. E. (2014). The effect of electric power fluctuations on the profitability and competitiveness of SMEs: A study of SMEs within the Accra Business District of Ghana. Journal of Competitiveness 6(3), 32-48.

17. Gill, A., Biger, N. \& Tibrewala, R. (2010). Determinants of dividend payout ratios: Evidence from United States, The Open Business Journal, 31(3), 8-13.

18. Green, C. J., Murinde, V. \& Suppakitjarak, J. (2012). Corporate financial structure in India. Economic Research Paper No. 02/4. Centre for International, Financial and Economics Research, Department of Economics, Loughborough University, Loughborough.

19. Karen, F. V., Erin, T. M. \& Qiong, W. (2015). Electricity shortages and firm productivity: Evidence from China's Industrial Firms. Journal of Development Economics 11(4), 172-188.

20. Kisengo, Z.M. \& Kombo, H. (2014). Effect of Firm Characteristics on Performance of the Microfinance Sector in Nakuru, Kenya, International Journal of Science and Research, 10,(3), 1791-1799.

21. Kouki, M. \& Guizani, M. (2009). Ownership structure and dividend policy evidence from the Tunisian stock market, European Journal of Science and Research, 25(1), 42-53.

22. Lai, J., Yik, F. \& Jones, P. (2008). Expenditure on operation and maintenance service and rental income of commercial buildings. Facilities, 26(5/6), 242-265.

23. Lebans, M. \& Euske, K. (2006). A Conceptual and Operational delineation of Performance, Business Performance Measurement. Cambridge University Press. 
24. Marithumu, F. (2019). Capital Structure and Financial Performance of South African State-Owned Entities. PhD Thesis, University of Kwa Zulu Natal.

25. Moyo, B. (2012). Do Power Cuts Affect Productivity? A Case Study of Nigerian Manufacturing Firms. International Business \& Economics Research Journal, 11(10), 1163-1173.

26. Myers, S. C. (1984). Corporate financing and investment decisions when firms have information that investors do not have. Journal of Financial Economics, 13(2), 187-221.

27. Myers, S.C. \& Majluf, NS. (1984). Corporate financing and investment decisions when firms have information that investors do not have, Journal of Financial Economics. 13(2): 187-195.

28. Nooij, M., Koopmans, C. \& Bijvoet, C. (2007). The value of supply security. The costs of power interruptions: Economic input for damage reduction and investment in networks, Energy Economics, 29, 277295.

29. Oladele, S. A., Omotunde, O. \& Adeniyi, SD. (2017). Effect of capital structure on the performance of Nigerian listed manufacturing firms, European Journal of Business and Management, 7(9), 21-32.

30. Oseni, M. \& Pollitt, M. (2013). The economic costs of unsupplied electricity: Evidence from backup generation among African firms. $\mathrm{PhD}$ Thesis. University of Cambridge, Faculty of Economics.

31. Saeedi, A. \& Mahmoodi, I. (2011). Capital Structure and Firm Performance: Evidence from Iranian Companies, International Research Journal of Finance and Economics, 70(7), 20-29.

32. Schoeman, T. \& Saunders, M. (2018). The Impact of Power Outages on Small Businesses in the City of Johannesburg. 10th Int'l Conference on Education, Business, Humanities and Social Sciences Studies, Cape Town (South Africa), 328-333.

33. Steinbuks, J. \& Foster, V. (2010). When do firms generate? Evidence on in-house electricity supply in Africa. Energy Economics, 32(3), 505-514.

34. Subrahmanyam, A. \& Titman, S. (2001). Feedback from stock prices to cash flows. Journal of Finance, 56(18), 2389-2413. 


\section{APPENDICES}

\section{Appendix I: Normality Test Summary for Individual Study Variables}

\section{Financial Performance}
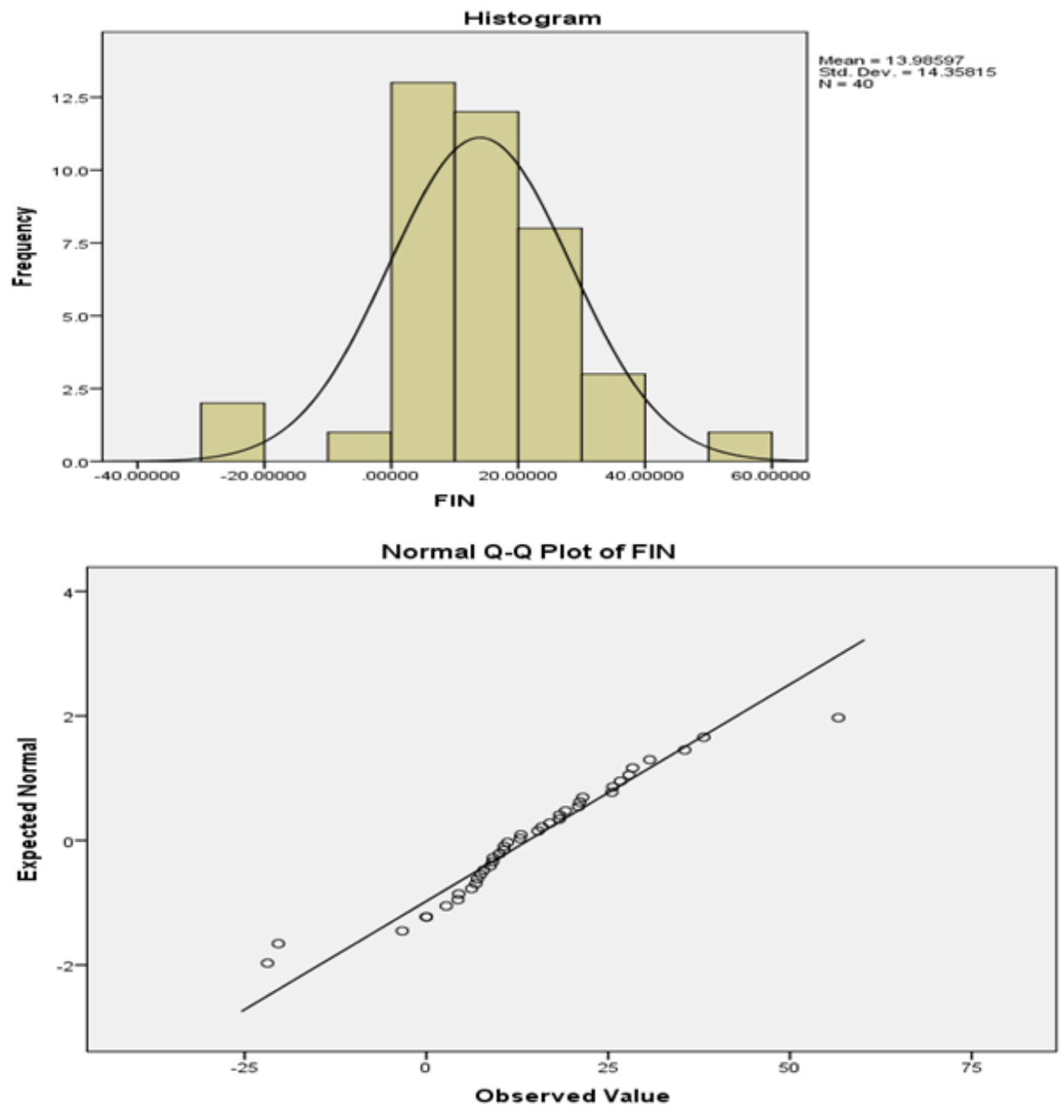
European Scientific Journal, ESJ

January 2021 edition Vol.17, No.1

\section{Power Outage Frequency}
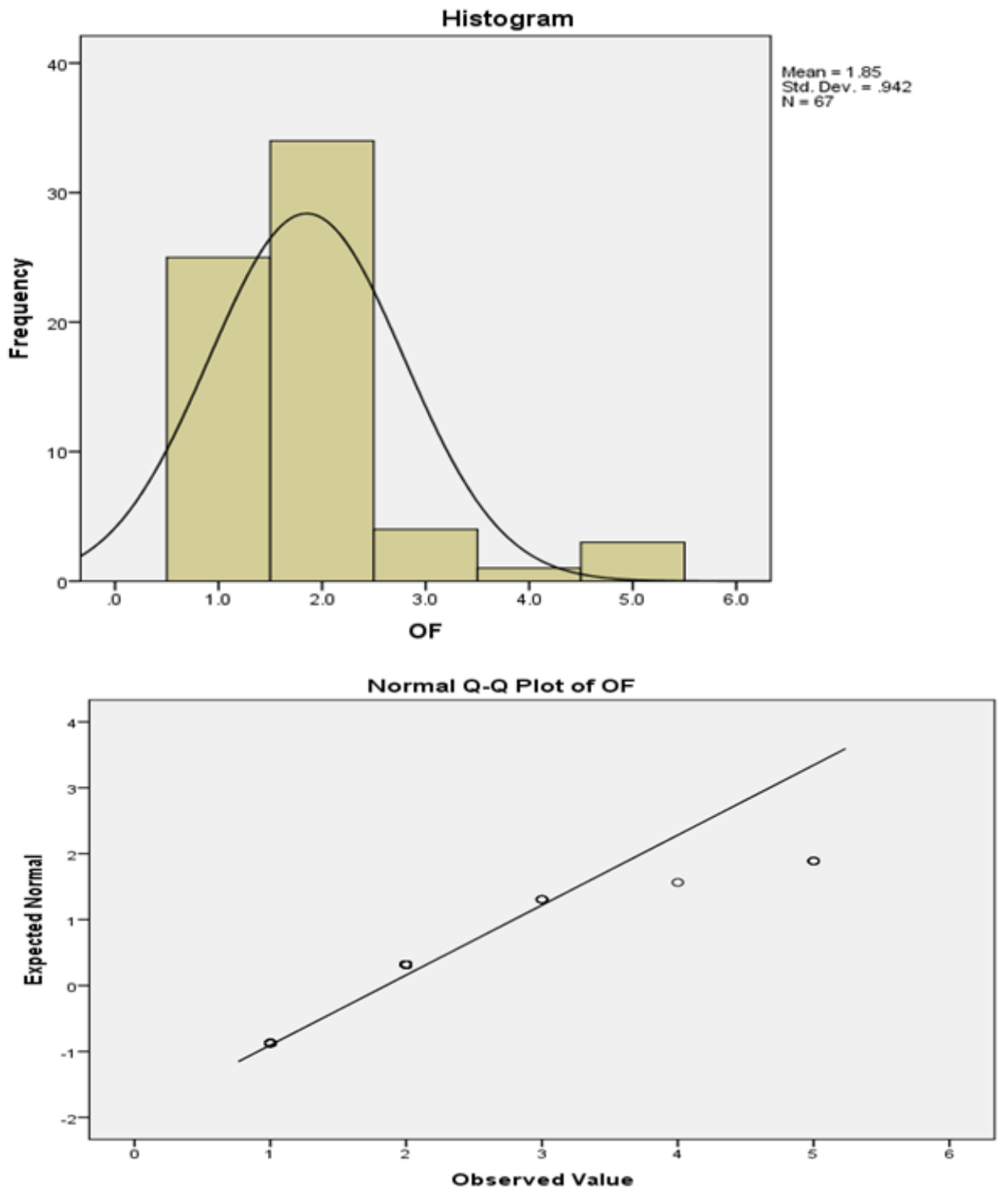